\title{
Feeding the nation in times of crisis: the relaxation of competition law in the United Kingdom
}

\section{Okeoghene Odudu*}

\begin{abstract}
In order to respond to the COVID-19 pandemic it has been recognized universally that cooperation between competitors will be necessary. It is also recognized that some of the cooperation contemplated will infringe competition law. A number of techniques are available by which conduct that infringes competition law can escape prohibition. Two techniques used have been to issue guidance on how the competition authority understands the law to apply and to articulate how it will exercise its discretion when deciding to take enforcement action. The combination of these two techniques provides a degree of comfort. In the United Kingdom, the government has gone further by identifying necessary cooperation and excluding such cooperation from competition law on grounds of public policy, in one instance for those in the groceries supply chain. The use of an exclusion order means that there is political accountability for the consequences the decision to set aside competition law will have, both for competitors, others in the supply chain, and for different consumer groups. For parties to excluded agreements, there is certainty ex ante that the cooperation is immune from competition challenge. Avoiding the need to assess the compatibility of an agreement with competition law, rather than permission to engage in incompatible behaviour, can be seen as the real value of the public policy exclusion order granted in relation to groceries.
\end{abstract}

Keywords: Competition Act 1998, public policy exclusion orders, self-assessment, enforcement, certainty

\section{Background}

A pneumonia of unknown cause was detected in Wuhan, China and reported to the World Health Organization on 31 December 2019. The outbreak was declared a Public Health Emergency of International Concern on 30 January 2020, named 'COVID-19' on 11 February 2020, and characterized as a pandemic on 11 March 2020. ${ }^{1}$ Government advice on social distancing resulted in people in the United Kingdom (UK) eating at home rather than eating out (the latter previously estimated at $30 \%){ }^{2}$ People were also concerned, not only about disruption that would result if the widespread closure of borders in mainland Europe was to prove necessary, but also that the UK government's response to COVID-19 would eventually include a lockdown. ${ }^{3}$

These factors prompted substantial changes in patterns of consumer demand, placing considerable pressure on those supplying essential goods and services, in particular, groceries. Alongside reports of 'heavily depleted shelves not just in items like toilet roll and pasta, but increasingly in meat, poultry and vegetables' - the Financial Times reported that 'supermarkets are lobbying the government to relax competition law to allow them to take steps to
Herchel Smith Senior Lecturer in Competition Law, Faculty of Law; Deputy Director, Centre for European Legal Studies; Fellow and Director of Studies in Law, Emmanuel College, University of Cambridge. This article is based on a paper that was presented as part of the Academic Society for Competition Law (ASCOLA) 'Competition Law in Isolation' series. It has been much improved by discussion with the seminar participants and further discussion with and comments from Or Brook, Francisco CostaCabral, Giorgio Monti, Simon Holmes, Kelvin Kwok, Rachel Burgess, Christopher Townley and Richard Whish. All views and errors remain my own and in accordance with the ASCOLA declaration of ethics, I confirm that I have nothing to disclose.
1 See World Health Organization, 'Coronavirus disease (COVID-19) Pandemic' homepage, available at: https://www.who.int/emergencies/ diseases/novel-coronavirus-2019.

2 Cabinet Office Guidance, 'Staying at home and away from others (social distancing)', available at: https://www.gov.uk/government/publications/ full-guidance-on-staying-at-home-and-away-from-others/full-guidanceon-staying-at-home-and-away-from-others\#delivering-these-newmeasures.

3 The lockdown eventually came on 23 March 2020: see Prime Minister address to the nation on coronavirus (23 March 2020), available at: https://www.gov.uk/government/speeches/pm-address-to-the-nation-oncoronavirus-23-march-2020. 
offset the risk of supply chain disruption as they introduced further rationing to combat a rise in stockpiling. ${ }^{4}$

On 19 March 2020, the Secretary of State for the Department of Environment, Food and Rural Affairs, George Eustice, following a meeting 'with chief executives from the UK's leading supermarkets and food industry representatives' at which he heard 'powerful arguments' concluded that 'relaxing elements of competition law' was necessary in order 'to allow supermarkets to work together to feed the nation' and so announced that 'elements of the law would be temporarily waived'. In addition, on 20 March 2020 the Competition and Markets Authority ('CMA') launched a COVID-19 taskforce, one function of which is to 'advise government on how to ensure competition law does not stand in the way of legitimate measures to protect public health and support the supply of essential goods and services' ${ }^{6}$

How should competition law apply in a crisis? ${ }^{7}$ In this article I set out the behaviour thought necessary to ensure the supply of essential products and why such behaviour constitutes an infringement of competition law under Chapter 1 of the Competition Act 1998 (the '1998 Act') and/or Article 101 TFEU (section 2). It is important to recognize that not all infringing behaviour is prohibited, as exemptions, exclusions, principles of administrative priority and other judicially recognized doctrines may apply to prevent the operation of the prohibition. The parties to an agreement that infringes competition law may therefore proceed if they are able to satisfy themselves not only that the criteria by which the prohibition is set aside are made out, but also, that in the event of challenge (without devoting too much resource) they will be able to satisfy a competition authority or court that the criteria setting aside the prohibition are made out. Section 3 of this article considers measures taken by the CMA to assure those infringing competition law in the public interest that they will have the prohibition set aside. The level of assurance provided by these measures is insufficient to encourage what is officially discouraged and section 4 of this article explains the ex ante exclusion from the Chapter I prohibition adopted by the UK government to provide certainty that any infringing behaviour parties have been encouraged to engage in in the public interest will escape sanction. Excluding conduct from competition law, even temporarily, is not without risk, and section 4 also explains the features of the measures adopted that minimize those risks. Section 5 concludes the article by asking why certain issues are best resolved by exclusion and placing this in the context of more general questions currently being asked about the function and purpose of competition law.

\section{The competition law obligation and its infringement}

The first issue is to identify the type of behaviour that is (a) ordinarily contrary to competition law, but (b) necessary to respond to the COVID-19 pandemic. In March 2020 it was announced that in order to 'keep shelves stocked and supply chains resilient' during the COVID-19 pandemic it would be necessary for grocery chain suppliers to 'work together on their contingency plans and share the resources they need with each other during these unprecedented circumstances'. ${ }^{8}$ Andrew Opie, Director of Food \& Sustainability at the British Retail Consortium, gave three reasons why it was necessary for firms to cooperate. First, to boost output to counter shortages retailers would need to agree common specifications. Secondly, in a situation where
4 J. Eley and J. Evans, 'Supermarkets raid restaurants to restock shelves', Financial Times (20 March 2020) and J. Eley, 'UK supermarkets take measures to control panic buying', Financial Times (18 March 2020).

5 Department for Environment, Food and Rural Affairs press release, Supermarkets to join forces to feed the nation (19 March 2020). On 17 April 2020 , in recognition that the 'dairy industry plays a crucial role in feeding the nation', the Secretary of State announced that the government would temporarily relax elements of UK competition law to support the dairy industry, enabling the industry to work together to address current market challenges: Department for Environment, Food and Rural Affairs press release, Dairy industry to join together to manage milk supply (17 April 2020). Unlike measures taken in relation to the grocery supply chain, the dairy industry exclusion order (The Competition Act 1998 (Dairy Produce) (Coronavirus) (Public Policy Exclusion) Order 2020, SI 2020/481) is intended to address what is envisaged to be short term excess supply, rather than excess demand. On 22 April 2020, the European Commission announced it would suspend the application of Article 101 TFEU to the milk, flowers and potatoes sectors, using powers contained in Article 222 of the Common Markets Organisation Regulation 1308/2013: see Commission press release, Coronavirus: Commission announces exceptional measures to support the agri-food sector (IP/20/722, 22 April 2020).
6 CMA, Guidance, CMA COVID-19 taskforce (20 March 2020), available at: https://www.gov.uk/government/publications/covid-19-cma-taskforce. The tone set by the CMA is very different from that set in a previous crisis by the then Commissioner Kroes, who was able to set out '[her] belief that competition policy was part of the solution to the crisis, not part of the problem': N. Kroes, 'Competition Policy and the Crisis - the Commission's Approach to Banking and Beyond' (2010) 55 The Antitrust Bulletin $715-26$, at 717.

7 This is not a new question and consideration of antecedent crises is given in T. Fisher, 'Antitrust during National Emergencies: I \& II' (1942) 40 Michigan L. Rev. 969, 1161; D. Crane, 'Did We Avoid Historical Failures of Antitrust Enforcement During the 2008-09 Financial Crisis?' (2010) University of Michigan Law \& Economics Working Papers 3, available at: https://repository.law.umich.edu/law_econ_current/art3; J. Fingleton, Competition Policy in Troubled Times (20 January 2009), available at: https:/publications.parliament.uk/pa/cm200809/cmselect/cmdereg/ memos/trends/m15a.pdf; Sir J. Vickers, 'The Financial Crisis and Competition Policy: Some Economics' December 08(1) Global Competition Policy 1-10; and OECD Global Forum on Competition, Policy Roundtable Crisis Cartels (October 2011) DAF/COMP/GF(2011)11, available at: https://www.oecd.org/daf/competition/cartels/48948847.pdf.

8 Supermarkets to join forces to feed the nation (fn 5). 
no single retailer can offer universal coverage, it is important for retailers to agree who will ensure which customers are provided for. Finally, in a situation of widescale staff absence due to illness across the supply chain it will be important to agree how continuity of service and supply is to be ensured. Further, in order to reach agreement on these matters it will be necessary to disclose or exchange information ordinarily considered to be competitively sensitive.

How are such arrangements viewed under competition law? The starting point is familiar - the Court of Justice, in Suiker Unie, explained that competition law imposes an obligation of independence, which requires

each economic operator [to] determine independently the policy which it intends to adopt on the [...] market including the choice of persons and undertakings to which he makes offers or sells. ${ }^{9}$

The Court of Justice has confirmed that the fact that independent action is replaced with cooperation with the object 'of remedying the effects of a crisis' is 'irrelevant for the purposes of applying [competition law]'. ${ }^{10}$ That the obligation of independence continues to apply in a shortage-of-supply crisis was made clear in the UK when, in September 2000, nervous motorists began panic buying fuel to beat an anticipated shortage caused by a number of farmers and lorry drivers establishing blockades of oil refineries. As road hauliers struggled to fuel their fleets and supply chains came under strain, panic buying shifted to supermarkets. ${ }^{11}$ The Office of Fair Trading ('OFT') reviewed measures taken to preserve the supply of oil fuels and, in the event of unavoidable supply disruption, to protect supplies to essential users and concluded that 'the stated aim "of protecting supplies to defined users" is a restriction of competition'. ${ }^{12}$ This was so because suppliers with a surplus would otherwise be expected to target the customers of suppliers with shortages. ${ }^{13} \mathrm{~A}$ further concern was raised by the exchange of information relating 'to the level and location of [...] stocks' that coordinated activity would necessitate, since such exchanges have 'the potential effect of preventing, restricting or distorting competition, both during and after an oil fuel emergency'. ${ }^{14}$

Is it possible to give confidence to parties seeking to engage in behaviour which they consider necessary to respond in the public interest to a situation arising from the COVID-19 pandemic, but which is well understood to infringe competition law, that the behaviour will not fall foul of the prohibition and will not be sanctioned? At the same time, how do we minimize the time and cost of obtaining the requisite degree of confidence? These are the challenges addressed in sections 3 and 4 below.

\section{Conditional forbearance and guidance on exemption}

Notwithstanding the fact that behaviour infringing competition law can be identified, the CMA (in line with other competition authorities around the globe) has given its assurance that enforcement action will not follow where cooperation is undertaken solely to ensure security of supply during the COVID-19 crisis and does not go further or last longer than is necessary. ${ }^{15}$
9 Joined Cases 40 etc./73 Coöperatieve Vereniging 'Suiker Unie' UA v. European Commission EU:C:1975:174, para 173.

10 Case C-209/07, Competition Authority v. Beef Industry Development Society Ltd and Barry Brothers (Carrigmore) Meats Ltd EU:C:2008:643, para 21. The Court was addressing the more familiar type of crisis, which arises in times of over-capacity rather than the present circumstances of shortages of supply, with which the present article is concerned. On the former, see B. Wardhaugh, 'Crisis Cartels: Non-economic Values, the Public Interest and Institutional Considerations' (2014) 10 European Competition Journal 311 and OECD Global Forum on Competition (fn 7).

11 B. Doherty, M. Paterson, A. Lows and D. Wall, 'Explaining the fuel protests' (2003) 5 British Journal of Politics and International Relations 1; and J. Burke, 'A few angry men', The Observer (17 September 2000).

12 OFT, Case CP/1730-00/S Memorandum of Understanding on the supply of oil fuels in an emergency (25 October 2001), para 40. On the consumer harm that would generally flow from standardization of non-price factors, see OFT, Response to the super-complaint on credit card interest rate calculation methods by Which? (OFT935, 26 June 2007).

13 Memorandum of understanding on the supply of oil fuels in an emergency (fn 12), para 57

14 Memorandum of understanding on the supply of oil fuels in an emergency (fn 12), paras 57 and 42 respectively (emphasis added). On 23 March 2020, and contrary to the established jurisprudence, the European Competition Network ('ECN') proclaimed that 'Considering the current circumstances, such measures are unlikely to be problematic, since they would either not amount to a restriction of competition under Article 101 TFEU/53 EEA or generate efficiencies that would most likely outweigh any such restriction': see ECN, Antitrust: Joint Statement by the European Competition Network (ECN) on application of competition law during the Corona crisis (23 March 2020), available at: https://ec.europa.eu/compe tition/ecn/202003_joint-statement_ecn_corona-crisis.pdf (emphasis added). The extent to which competition law is infringed by an agreement designed to increase supply is uncertain, but see Case C-238/05 AsnefEquifax, Servicios de Información sobre Solvencia y Crédito, SL v. Asociación de Usuarios de Servicios Bancarios (Ausbanc) EU:C:2006:734, paras $46-63$, in which an agreement that is intended to result in improvements in the supply of credit is discussed.

15 See CMA press release, COVID-19: CMA approach to essential business cooperation (19 March 2020); CMA, CMA approach to essential business cooperation (CMA 118, 25 March 2020), paras 1.5 and 2.3; ECN Joint Statement (fn 14); and International Competition Network Steering Group Statement, Competition during and after the COVID-19 Pandemic (8 April 2020) available at: https://www.internationalcompetitionnetwork. org/wp-content/uploads/2020/04/SG-Covid19Statement-April2020.pdf. It has been proposed that a notification regime be created, and that forbearance be shown only in relation to conduct taken in relation to COVID-19 that has been notified: F. Costa-Cabral, L. Hancher, G. Monti and A. Ruis Feases, EU Competition Law and COVID-19, TILEC Discussion Paper DP 2020-007, available at: https://ssrn.com/abstract=3561438. The U.S. Department of Justice and Federal Trade Commission will provide expedited review and business review letters: Joint Antitrust Statement 
Although it has enhanced efforts to identify 'unscrupulous businesses exploiting the crisis' the CMA has:

no intention of taking competition law enforcement action against cooperation between businesses or rationing of products to the extent that this is necessary to protect consumers - for example, by ensuring security of supplies. ${ }^{16}$

The assurance of forbearance is of limited value for two main reasons. First, it cannot protect the parties from action if the authority does not have exclusive jurisdiction to enforce the law. It therefore offers limited protection against action the European Commission ('Commission') might wish to take under Article 101 TFEU and from private parties who may be harmed by a competition law infringement, even if there may be a benefit to the broader public. ${ }^{17}$ The risk of challenge by anyone other than the CMA will be determined by the impact of the agreement on the businesses of third parties, or the interests of consumers, that would ordinarily be protected by competition law. An investigation into the facts of any specific agreement may alter the assessment of that agreement's virtue and it would be wrong to prevent such matters being aired before a court. The second factor limiting the value of the assurance is that whether the conditions on which the assurance is given have been made out is determined ex post by the competition authority. ${ }^{18}$ What seems obviously justified in the middle of a crisis may well look different in the eyes of a regulator, court or complainant a few years down the line when the crisis is over. How, for example, will the CMA determine that concerns arise solely from the current crisis? Or that a less restrictive

Regarding COVID-19 (24 March 2020), available at: https://www.justice. gov/atr/joint-antitrust-statement-regarding-covid-19. This should be compared with the US agencies' earlier guidance in Antitrust Guidance Hurricanes Harvey and Irma (12 September 2017, available at: https:// www.ftc.gov/system/files/documents/public_statements/1253313/hurricanes_ harvey_and_irma_ftc_doj_statement.pdf) and Antitrust Guidance Hurricanes Katrina and Rita (25 June 2015, available at: https://www.justice.gov/atr/ antitrust-guidance-hurricanes-katrina-and-rita).

16 See CMA approach to essential business cooperation (fn 15), in particular paras 1.1-1.5 and 1.7.

17 See CMA approach to essential business cooperation (fn 15), para 4.1. Brook points out that the factors used to determine forbearance differ from the factors used to determine the existence of an infringement or the criteria for exemption: O. Brook, Priority-Setting as a Double-Edged Sword: How Modernisation Strengthened the Role of public policy (20 April 2020), available at: https://papers.ssrn.com/sol3/papers.cfm? abstract_id=3580837.

18 The ECN assurance of forbearance is similarly conditional on a finding by the authorities that action is 'necessary and temporary' and intended to 'avoid a shortage of supply': ECN Joint Statement (fn 14).

19 CMA approach to essential business cooperation (fn 15), paras 3.4(c) and 4.2. See also the text accompanying fn 32 below.

20 It is clear that the CMA's guidance does not bind other competition authorities, courts or private parties: CMA approach to essential business cooperation (fn 15), para 4.1. See also Commission Notice on informal guidance relating to novel questions concerning [Articles 101 and 102 TFEU] that arise in individual cases [2004] OJ C 101/78, para 25. response was not available? Firms will need to self-assess whether their actions meet the authority's stated criteria. In determining whether measures are necessary the CMA does, however, provide useful clarification that it considers the 'limited time available to consider alternatives' to be a 'key factor', and is willing to provide informal guidance to help assuage the parties' concerns. ${ }^{19}$

Alongside the assurance of forbearance, the CMA also issued guidance setting out when it believes an infringement will satisfy the criteria set out in section 9 of the 1998 Act and so qualify for exemption from the prohibition. ${ }^{20}$ The aim here is to resolve uncertainty over the exemption criteria, particularly the extent to which broader public policy benefits of infringing conduct form part of that assessment. ${ }^{21}$ In 2001, the OFT concluded that the exemption criteria were satisfied by an arrangement that would

preserve the supply of fuel oils and, in the event of unavoidable supply disruption ... protect ... supplies to defined essential users. This would not necessarily happen as a result of free and competitive market forces during the period surrounding an oil fuel emergency since supplies would be delivered to the highest bidder. ${ }^{22}$

It seems, therefore, that preventing a price increase that would result from bidding in a situation of extreme scarcity, and ensuring a fair allocation of goods when willingness and ability to pay fail properly to determine such an allocation, are recognized as benefits that may outweigh the general obligation of independence. Though not referring to the OFT's 2001 Memorandum of Understanding decision, the CMA's view is that

21 Joined Cases T-528 etc. $/ 93$ Métropole Télévision SA v. Commission EU: T:1996:99, para 118. See also OFT, 'Article 101(3) - A Discussion of Narrow versus Broad Definition of Benefits' (Discussion note for OFT breakfast roundtable 2010); G. Monti, 'Article 81 EC and Public Policy' [2002] 39 C.M.L.Rev. 1057; C. Townley, Article 81 EC and Public Policy (Hart 2009) and A Witt, 'Public Policy Goals under EU Competition Law: Now is the Time to Set the House in Order' (2012) 8(3) European Competition Journal 443 perhaps offer the classic treatment. The claim is particularly vociferous in environmental law, and particularly in relation to cooperation in response to climate change: see e.g. S. Kingston, Greening EU Competition Law and Policy (Cambridge University Press, 2012), A. Gerbrandy, 'Solving a Sustainability-Deficit in European Competition Law' (2017) 40(4) World Competition 539; O. Brook, 'Struggling with Article 101(3) TFEU: Diverging Approaches of the Commission, EU Courts, and Five Competition Authorities' [2019] 56 C.M.L.Rev. 56; and F. Gomez-Martinez, S. Ondeistal and M. Schinkel, 'Can Collusion Promote Corporate Social Responsibility? Evidence from the Lab', Amsterdam Law School Research Paper No 2019-13, available at: http://ssrn. com/abstract $=3372917$.

22 Memorandum of understanding on the supply of oil fuels in an emergency (fn 12), para 62. Although the OFT ultimately granted an individual exemption in the supply of fuel, the exemption has now expired and the issues it raised are instead addressed by The Competition Act 1998 (Public Policy Exclusion) Order 2012, SI 2012/710. See also Explanatory Memorandum, para 7.3, available at: https://www.legislation.gov.uk/uksi/2012/ 710/pdfs/uksiem_20120710_en.pdf. 
measures taken to ensure security of supply or avoid shortages of scarce products do meet the criteria for exemption set out in section 9 of the 1998 Act. $^{23}$

The CMA's COVID-19 guidance may succeed in clarifying the role played by broader public policy concerns in the decision to set aside the prohibition. It may also portend a new willingness to re-introduce criteria hitherto excluded from a competition law assessment. However, though the parties must assess for themselves whether the criteria for exemption are satisfied, they may not themselves determine that the criteria are satisfied. ${ }^{24}$ The determination is made ex post either by the CMA or by a court. In its review of the self-assessment regime under Regulation 1/2003, the Commission reports that 'some stakeholders claim that a lack of legal certainty deters companies from pursuing certain [action] that they would have contemplated with the protection of notification'. ${ }^{25}$ It has been known for a long time that certainty that the criteria for exemption are made out to a standard that will satisfy a competition authority and a standard that will also dissuade private parties from challenging conduct before a court cannot be obtained within the self-assessment regime. ${ }^{26}$ This is recognized in the Explanatory Memorandum to the Competition Act (Public Policy Exclusion) Order 2012. The exclusion from competition law was justified on the basis that the UK government had reached the conclusion that the petroleum industry would not respond to requests by it to cooperate in the public interest in a timely manner because

there will be a delay before actions can be taken whilst industry makes the assessment and furthermore industry considers there would remain an unacceptable risk of challenge on competition law grounds, which even successfully defended, which is the expected outcome, the significant time and resource

23 CMA approach to essential business cooperation (fn 15), para 3.4.

24 See Wardhaugh (fn 10), at 336-40 (discussing what he describes as the institutional competence or legitimacy problem) and O. Odudu, 'Article 81(3), Discretion \& Direct Effect' (2002) E.C.L.R. 17.

25 Commission Staff Working Paper accompanying the Report on the functioning of Regulation 1/2003, SEC (2009) 206 final, paras 46 and 47, available at: https://op.europa.eu/en/publication-detail/-/publication/ 378cf62f-c4a6-4499-82f5-3bbf3887e37b/language-en.

26 See, on the lack of legal certainty, European Commission, Factual summary of the contributions received during the public consultation on the evaluation of the two block exemption regulations and the guidelines on horizontal cooperation agreements (2019), pp. 6-8, available at: https:// ec.europa.eu/competition/consultations/2019_hbers/HBERs_consultat ion_summary.pdf.

27 Explanatory Memorandum to The Competition Act (Public Policy Exclusion) Order 2012 (fn 22).

28 See ECN, Decision-Making Powers Report (31 October 2012), available at: https://ec.europa.eu/competition/ecn/decision_making_powers_report_en. pdf.

29 ACCC, Coles Group Limited - Application for authorisation AA1000477, Interim authorisation decision (23 March 2020). See also, in Hong spent in defending any challenges would make industry reluctant to engage in the activities. ${ }^{27}$

There are limits to the degree of certainty a competition authority can provide in the absence of a notification regime and an obligation to reach a decision. ${ }^{28}$ In Australia, where the competition authority is able to set competition law aside, the Australian Competition and Consumer Commission ('ACCC') has issued an interim authorization, conferring immunity and allowing the parties to proceed, whilst a full investigation is conducted. ${ }^{29}$ Certainty can be provided by the Commission under Article 10 of Regulation 1/2003, which permits the Commission to adopt a 'finding of inapplicability', either because the conditions of Article 101(1) TFEU are not fulfilled, or because the conditions of Article 101(3) TFEU are satisfied. Such a decision would be binding on national courts and competition authorities. ${ }^{30}$ The Commission is, however, adamant that the function of Article 10 is not to reduce legal uncertainty, since 'the risk of having to defend their case before a national court is in principle the same for all undertakings'. ${ }^{31}$ Instead, Article 10 is simply one of a number of tools available to the Commission to avoid inconsistent outcomes in a decentralized system of enforcement. As such, the Commission has not had occasion to adopt an Article 10 decision. In relation to novel or unresolved questions the Commission instead is committed to providing informal guidance letters. $^{32}$ The Notice on Informal Guidance is, however, clear:

Guidance letters are not Commission decisions and do not bind Member States' competition authorities or courts that have the power to apply Articles [101] and [102]. However, it is open to Member States' competition authorities and courts to take account of guidance letters issued by the Commission as they see fit in the context of a case. ${ }^{33}$

Kong, Hong Kong Competition Commission, Statement by the Competition Commission regarding the COVID-19 outbreak (27 March 2020).

30 European Commission, DG Competition, Antitrust Manual of Procedures Internal DG Competition working documents on procedures for the application of Articles 101 and 102 TFEU (March 2012), Ch 18, paras 30-32, available at: http://publications.europa.eu/resource/cellar/cd7d54b9-dd4545fb-94e9-7d761533a8b1.0001.03/DOC_1.

31 Antitrust Manual of Procedures (fn 30), Ch 18, para 5.

32 European Commission, Communication, Temporary Framework for assessing antitrust issues related to business cooperation in response to situations of urgency stemming from the current COVID-19 outbreak (2020/C 116 I/02), para 7, available at: https://ec.europa.eu/info/sites/info/files/framework communication_antitrust issues_related to cooperation between competitors_in_covid-19.pdf and European Commission, Comfort letter: coordination in the pharmaceutical industry to increase production and to improve supply of urgently needed critical hospital medicines to treat COVID-19 patients, Medicines for Europe (8 April 2020; available at: https://ec.europa.eu/competition/antitrust/medicines_for_europe_comfort letter.pdf). See more generally, Commission Staff Working Paper accompanying the Report on the functioning of Regulation 1/2003 (fn 25), paras 44 and 45 .

33 Commission Notice on informal guidance (fn 20), para 25. 
Greater certainty can be provided by the promulgation of block exemption regulations. Section 6 of the 1998 Act allows the Secretary of State, acting upon a recommendation from the CMA, to adopt block exemptions. A block exemption may be of limited duration and may contain conditions and obligations. ${ }^{34}$ The use of a block exemption would raise more clearly the question of whether section 9 allows public interest concerns to be considered and how they are to be balanced against other objectives in a particular sector or in particular types of agreement. The procedure for adopting block exemptions is set out in section 8 and the time taken to complete the procedural steps militates against their use on this occasion. The pressure placed on the groceries supply chain and how competition law would treat action to address those pressures called for certainty to be provided quickly and it is to the instruments adopted to meet this particular challenge that I now turn.

\section{The Groceries Public Policy Exclusion Order}

In addition to the concept of exemption that exists under section 9 of the 1998 Act (mirroring Article 101(3) TFEU), Schedule 3(7) of the 1998 Act enables the Secretary of State to make an order excluding the application of the Chapter I prohibition if satisfied that there is an exceptional and compelling reason of public policy to do so. Satisfied of the need for coordination in order to withstand the pressure COVID-19 placed on the groceries supply chain, on 27 March 2020 The Competition Act 1998 (Groceries) (Coronavirus) (Public Policy Exclusion Order) 2020 ('Groceries PPEO') was made, along with an Explanatory Memorandum. ${ }^{35}$ The Groceries PPEO came into force on 28 March 2020, but covers conduct entered into from 1 March 2020.36

The Groceries PPEO applies when the purpose of the agreement is to prevent or mitigate disruption to the supply of groceries to consumers in any part of the

341998 Act, ss 6(5) and 6(7).

35 The Competition Act 1998 (Groceries) (Coronavirus) (Public Policy Exclusion) Order 2020, SI 2020/369. In addition, four further exclusion orders have been promulgated: The Competition Act 1998 (Health Services for Patients in England) (Coronavirus) (Public Policy Exclusion) Order 2020, SI 2020/368; The Competition Act 1998 (Solent Maritime Crossings) (Coronavirus) (Public Policy Exclusion) Order 2020, SI 2020/ 370; The Competition Act 1998 (Health Services for Patients in Wales) (Coronavirus) (Public Policy Exclusion) Order 2020, SI 2020/435; and The Competition Act 1998 (Dairy Produce) (Coronavirus) (Public Policy Exclusion) Order 2020, SI 2020/481.

36 Groceries PPEO, articles 1 and 6(3).

37 Groceries PPEO, article 5(2)(a).

38 The Groceries PPEO, articles 4 and 6, also permits five kinds of agreements between logistics service providers.
UK by a reason relating to coronavirus. ${ }^{37}$ It enables undertakings in the grocery supply chain to agree on eight specific matters they would otherwise be obliged to determine independently. ${ }^{38}$ In addition to allowing the exchange of information, under articles 3(2)(d) and $3(2)$ (e) (excluding price information, by virtue of article $3(1)(b))$, the Groceries PPEO provides that groceries supply chain suppliers may collaborate:

- In relation to limits on the number of a particular grocery item that a consumer may purchase (article 3(2)(a)). Thus, on 18 March 2020, large grocery retailers announced that shoppers would be restricted to a maximum of three of any of the same grocery item - and just two of the most in-demand products (toilet paper, cleaning products, UHT milk and paracetamol).

- In relation to staff redeployed from other industries (article 3(2)(b))..$^{39}$ The surge in consumer demand, government guidance that those with (or living with someone displaying) certain symptoms stay home for up to 14 days, and guidance that extremely vulnerable persons stay home for 12 weeks, presented retailers with the risk of staff absences. One large retailer announced that over the period it had recruited an additional 47,000 members of staff to cover those absences. ${ }^{40}$ Staff were also redeployed from firms in the hospitality sector. ${ }^{41}$

- In relation to the range of groceries to be made available (article 3(2)(c)). On 18 March 2020, the chief operating officer of a large groceries retailer reported that 'cutting range options had allowed the company to package 5,300 tonnes of potatoes and carrots last week against 4,100 the week before'. ${ }^{42}$ A supplier of own-label toilet paper and kitchen roll had reduced its range of tissue types from 120 to 30 so that more could be manufactured quickly. ${ }^{43}$ The extent to which action under article $3(2)(c)$ results in a shift away from branded goods towards private label goods, and the extent to which that shift is reversible (and at what cost) remains to be seen.

- In how they meet commitments to assist particular groups of customers, for example critical workers and vulnerable groups (article 3(2)(f)). So far, we

39 Competition law concerns that may arise in the operation of the labour market during the pandemic are highlighted in the US Department of Justice and Federal Trade Commission Joint Antitrust Statement Regarding COVID-19 and Competition in Labor Markets (13 April 2020), available at: https://www.ftc.gov/news-events/press-releases/2020/04/federal-tradecommission-justice-department-issue-joint-statement.

40 S. Butler, 'How Tesco's 'doomsday exercise' helped it cope with the coronavirus', The Guardian (3 May 2020).

41 F. Briggs, 'Innovative thinking necessary for businesses to navigate the Covid-19 crisis', Retail Times (3 April 2020).

42 'UK supermarkets take measures to control panic buying' (fn 4).

43 'UK supermarkets take measures to control panic buying' (fn 4). The CMA has indicated that it will not take enforcement action against agreements leading to a reduction in choice during the COVID-19 pandemic: CMA approach to essential business cooperation (fn 15), para 2.5 . 
have seen special opening times for seniors and NHS workers and allocation of home delivery services to those identified by the government as extremely vulnerable.

- In their opening hours (article $3(2)(\mathrm{g})$ ). Stores normally open 24 hours have operated restricted opening hours. The reduced opening hours have enabled the remainder of the time and staff to be engaged in fulfilling home shopping orders. ${ }^{44}$ It has also allowed for restocking. Groceries retailers have also closed labour-intensive parts of their large stores (such as pizza counters, fishmongers and butchers) so that more staff are available on the shop floor.

Agreements covered by the Groceries PPEO are not automatically excluded from the Chapter I prohibition and benefit only if they are notified to the Secretary of State within 14 days of being concluded (or of the Order coming into force). ${ }^{45}$ The notification must set out the parties to, and date of, the agreement, a description of its nature and the groceries to which it relates. The Secretary of State must maintain and publish a register of notified agreements. ${ }^{46}$ There is clearly no intention to conceal these arrangements. Such a process is surely sufficient to satisfy section $188 \mathrm{~B}$ of the Enterprise Act 2002 (the '2002 Act'), and so removes the possibility of prosecution under the UK's criminal cartel offence. As envisaged by section 188B of the 2002 Act, publication should also act as effective 'soft' regulation, as it enables third party scrutiny and so should deter those engaged in unmeritorious arrangements from exploiting the exclusion available. ${ }^{47}$ Unlike assurances of forbearance and reliance on guidance, the process instituted by the Groceries PPEO is transparent. Much will be learnt by examining the agreements published on the register. What is clear is that the decision to grant an exclusion from competition law is political. Since the balance between competition concerns and wider public concerns is also a political or at any rate, not straightforwardly a legal, question, the use of an exclusion order seems the correct route by which to determine the balance of competing interests. ${ }^{48}$

Four issues with the Groceries PPEO remain to be addressed. The first is the nature of the Order. Does the Order exempt behaviour otherwise incompatible with competition law, or merely absolve the parties from the burden of assessing an agreement's compatibility with competition law (and provide immunity from suit during the period in which the assessment obligation is suspended)? Secondly, the process by which a public policy exclusion order is obtained remains opaque. Thirdly, how do we ensure that competition, suspended during the COVID-19 pandemic, returns (with vigour) once the crisis is over? The final issue is whether conduct excluded from the Chapter I prohibition remains subject to Article 101 TFEU, so that the Groceries PPEO offers merely a simulacrum of exclusion. These issues are considered in turn.

\subsection{The nature of a public policy exclusion order}

What is the nature of an agreement that is subject to a public policy exclusion order? So rarely have such orders been made that the answer is not entirely clear, though on its face an excluded agreement is one to which the 1998 Act does not apply at all. ${ }^{49}$ One idea is that exclusion is required because the necessary arrangements infringe the Chapter I prohibition and do not benefit from exemption provided by section 9 of the 1998 Act. If so, firms should not notify agreements under the Groceries PPEO if analysis shows that the Chapter I prohibition is not infringed or the benefit of exemption under section 9 can be claimed. This is particularly the case in relation to any types of arrangement they have entered into in the past or might wish to enter in the future outside the context of the COVID-19 pandemic (the existence of which would not be known outside the transparency provided for by articles 8 and 9 of the Groceries PPEO).
44 'How Tesco's "doomsday exercise" helped it cope with the coronavirus' (fn 40).

45 Groceries PPEO, article 8.

46 Groceries PPEO, article 9. On 21 May 2020 a register of agreements relating to exclusion orders made by powers under paragraph 7 of Schedule 3 to The Competition Act 1998, available at https://www.gov.uk/guidance/ competition-law-exclusion-orders-relating-to-coronavirus-covid-19? utm_source $=$ ddbcdc56-e883-45e8-aeaa-60fbe2472312\&utm_medium $=\mathrm{e}$ mail\&utm_campaign=govuk-notifications\&utm_content=immediate.

47 Publication counters an objection to exclusion or exception: J. Fingleton, 'Competition Policy in Troubled Times' (Office of Fair Trading, 20 January 2009), p. 9, available at: https://publications.parliament.uk/pa/cm200809/ $\mathrm{cmselect/cmdereg/memos/trends/m15a.pdf.}$

48 See further, Wardhaugh (fn 10), at 336-340; and A. Chisholm, Competition and politics: what does a healthy relationship look like?, speech given at Chatham House conference 'Politicisation of Competition Policy' (19 June 2015), available at: https://www.gov.uk/government/speeches/ alex-chisholm-speaks-about-competition-and-politics.
49 M. Coleman and M. Grenfell, The Competition Act 1998: Law and Practice (Oxford University Press, 1999), para 5.02. Prior to COVID-19 four exclusion orders have been made under Schedule 3(7) to the 1998 Act. Three exclusion orders relate to the defence industry, and reflect an absence of an equivalent to Article 346 TFEU in the 1998 Act: The Competition Act 1998 (Public Policy Exclusion) Order 2006, SI 2006/605 (maintenance and repair of warships); The Competition Act 1998 (Public Policy Exclusion) Order 2007, SI 2007/1896 (strategic and tactical weapons and their supporting technology), repealed with effect from 30 December 2011 by The Competition Act 1998 (Public Policy Exclusion) (Revocation) Order 2011, SI 2011/2886; and The Competition Act 1998 (Public Policy Exclusion) Order 2008, SI 2008/1820 (design, construction, maintenance and disposal of nuclear submarines). The fourth public policy exclusion order, The Competition Act 1998 (Public Policy Exclusion) Order 2012, SI 2012/710, follows the expiry of the exemption granted in Memorandum of Understanding on the supply of oil fuels in an emergency (fn 12). 
The problem with this first approach will be immediately apparent - it adds to the complexity of competition law analysis at a time when what is being called for is simplification of the process by which legal certainty can be obtained. A better view is therefore that a public policy exclusion order is not necessarily made because an agreement infringes the Chapter I prohibition or does not benefit from exemption under section 9. Instead, a public policy exclusion order may be made to confer ex ante legal certainty without the need for any legal or economic analysis to take place at all. ${ }^{50}$ What is being weighed is not the impact of harm to competition against the wider public benefit of a measure, but the risk of anti-competitive harm against: (a) potential wider public benefits, and (b) the benefit from forgoing any competition law analysis, which in the case of the Groceries PPEO is speed of action at a time of a serious and immediate public health crisis. Under this approach, firms would notify agreements in lieu of analysing their agreement's compatibility with competition law. This interpretation is consistent with other exclusion orders available under the 1998 Act. For example, land agreements had previously been excluded from the scope of the 1998 Act. ${ }^{51}$ This exclusion has now been revoked. ${ }^{52}$ The Explanatory Memorandum to the revocation order explains that exclusion had been provided for practical reasons, and that the excluded agreements were 'no more or less capable of resulting in a restriction of competition in markets than any other type of agreement'. ${ }^{53}$ The benefit of an exclusion order is obtained simply by avoiding the need to conduct a competition law assessment, and removing the risk of proceeding without such an assessment. It does not involve balancing harm to competition against other public values within competition law. ${ }^{54}$

\subsection{The process by which a public policy exclusion order is sought or granted}

It is apparent that the process by which agreements are excluded by Ministerial order on grounds of public policy remains, although not quite a secret body of jurisprudence, opaque. Unlike a block exemption, which has a procedure set out in section 8 of the 1998 Act, the 1998 Act is silent on how a PPEO is to be obtained. This lack of transparency is in stark contrast to the use of public interest grounds in merger assessment under the 2002 Act. ${ }^{55}$ Here, the procedure for assessing public interest issues begins with an intervention notice (or, as appropriate, a special intervention notice) issued by the Secretary of State. The notice must identify the merger concerned and the public interest considerations relevant to the merger. ${ }^{56}$ The CMA is obliged to report on both the impact on competition and the impact on other public interests. ${ }^{57}$ How to proceed is, in relation to public interest considerations, a decision taken by the Secretary of State. Unlike the PPEO, there is a transparent balancing of harm to competition against identified public interests that may require the interest in competition to be set aside competition law obligations. The same procedure and level of transparency may not be required in the case of PPEOs, not least if what is excluded is the burden of self-assessment in situations when the benefit of the conduct is great and the risk of competitive harm is low. However, a question that will resurface is why some interests or industries are afforded this advantage and, in this context, we should heed the imploration of the previous chief executive of the CMA that:

it is vitally important that whatever the nature of [a competition authority's] dealings with politicians, they should be as transparent as possible. ... [It is] better instead to acknowledge the existence of such dealings and to make them open and transparent. ${ }^{58}$

\subsection{Business as usual and the importance of active supervision}

A question raised by Ormosi and Stephan is how can we be sure the coordination does not go beyond what is
50 Impact assessments were not carried out before the Covid-19 PPEOs were adopted, reflecting the emergency nature of the legislation, which will be in place for a limited period of time: see e.g. the Explanatory Memorandum to the Groceries PPEO (fn 27), para 12.3.

51 The Competition Act 1998 (Land Agreements Exclusion and Revocation) Order 2004, SI 2004/1260.

52 The Competition Act 1998 (Land Agreements Exclusion Revocation) Order 2010, SI 2010/1709.

53 Explanatory Memorandum to The Competition Act 1998 (Land Agreements Exclusion Revocation) Order 2010, 2010/1709, para 7.2, available at: http:// www.legislation.gov.uk/uksi/2010/1709/pdfs/uksiem_20101709_en_001.pdf.

54 The Explanatory Memorandum to the Groceries PPEO (fn 27), is ambiguous Although it states, at para 7.3, that the matters covered by the Groceries PPEO 'would ordinarily breach domestic competition rules' it is silent on whether

\footnotetext{
s 9 of the 1998 Act would be satisfied. This ambiguity does not exist in the Explanatory Memorandum to the Competition Act (Public Policy Exclusion) Order 2012 (available at: http://www.legislation.gov.uk/uksi/2012/710/pdfs/ uksiem_20120710_en.pdf), which at para 7.3, clearly states that the conditions set out in s 9 of the 1998 Act are satisfied.

552002 Act, ss 45(2)(d) and 45(4)(d).

562002 Act, s 43(2).

57 See OFT, Anticipated acquisition by Lloyds TSB plc of HBOS plc: Report to the Secretary of State for Business Enterprise and Regulatory Reform (24 October 2008). See also a dossier of evidence released under the Freedom of Information Act 2000, available at: https://webarchive.nationalarchives. gov.uk/20121204165709/http://www.bis.gov.uk/assets/BISCore/corporate/ docs/foi/foi-evidence-decision-on-lloyds-tsb-merger-hbos.pdf.

58 A. Chisholm (fn 48)
} 
necessary and that it will stop once the crisis is over?'59 The Chair of the ACCC, Rod Sims, raised a similar concern in remarks at the Gartner CEO Forum, noting that it would be extremely unfortunate if this pandemic were to see a consolidation in the grocery sector as supplies narrow to supermarkets in ways that will be hard to reverse' ${ }^{60}$ One answer offered by the Groceries PPEO is that agreements must be notified in order to benefit from exclusion. ${ }^{61}$ Article 7 of the Groceries PPEO sets outs the terms on which exclusion of notified agreements is brought to an end. Given what is said above about the nature of an exclusion order, in relation to the continuation of an arrangement, the compatibility of an agreement with competition law will then fall to be assessed. The deeper issue raised by Ormosi and Stephan is that the parties to an anti-competitive arrangement will be unable to purge themselves of knowledge gained during the period of exclusion, and future action will be guided by that knowledge - a phenomenon described as 'residual collusion'. ${ }^{62}$ The Groceries PPEO seeks to mitigate the risk of residual collusion by excluding from its scope exchanges of commercially sensitive information relating to costs or pricing. ${ }^{63}$ The CMA's guidance creates some ambiguity because it includes exchanges of commercially sensitive information on future pricing in the measures it will challenge only 'where this is not necessary to meet the needs of the current situation' ${ }^{64}$ It is unclear how the CMA will determine that exchanging information on pricing is unnecessary. For example, is it necessary when agreeing with a common supplier on a common specification (as envisaged by the Groceries PPEO) to also discuss how the cost of meeting production to that specification will be allocated and amongst whom?

\subsection{The compatibility of excluded behaviour with EU law}

A final question is whether conduct benefiting from the Groceries PPEO under the 1998 Act nonetheless remains

59 P. Ormosi and A. Stephan, 'Should competition law be suspended to help deal with the COVID-19 crisis?', Competition Policy Blog (27 March 2020), available at: https://competitionpolicy.wordpress.com/2020/03/27/shouldcompetition-law-be-suspended-to-help-deal-with-the-covid-19-crisis/ \#more-1427.

60 R. Sims, Managing the impacts of COVID-19 disruption on consumers and business, remarks to the Gartner CEO Forum (8 April 2020), available at: https://www.accc.gov.au/speech/managing-the-impacts-of-covid-19-disrup tion-on-consumers-and-business (emphasis added). See also J. Fingleton (fn 7), p 8.

61 Groceries PPEO, article 8

62 Also see Memorandum of understanding on the supply of oil fuels in an emergency (fn 12), paras 42 and 57. J. Harrington Jr, 'Post-Cartel Pricing during Litigation' (2004) 52 Journal of Industrial Economics 517, explains that transition effects may be the result of residual collusion but may also be result from the prospect of litigation and damages. Since the Groceries PPEO removes the prospect of litigation, transition effects would not persist on this basis. exposed to action under Article 101 TFEU, assuming an effect on inter-state trade. With competition authorities indicating their unwillingness to intervene in relation to necessary cooperation, the general view also appears to be that the risk of private action is low. The editors of Bellamy \& Child however give a clear warning that undertakings acting under national legislation:

that facilitates or purports to legitimise anti-competitive conduct by undertakings ... may contravene the [EU] competition rules notwithstanding the legislation. An agreement or conduct which is not required by law may be caught by the competition rules even if it is done following consultation with the national authorities, or with their encouragement or approval, and even if it is later expressly ratified by national law. ${ }^{65}$

There is an emerging consensus that the range of responses necessary to ensure continuity of supply of essential goods during the COVID-19 pandemic are compatible with EU competition law. The debate is about the basis on which the arrangements are compatible with the Treaty. ${ }^{66}$ One issue to explore is the extent to which the fact that the government oversees the excluded arrangements provides the parties to those arrangements with cover.

In the UK it is acknowledged that 'the Environment Secretary continues to meet regularly with representatives of the food industry to ensure people can get the food and groceries they need'. ${ }^{67}$ This is a very clear indication that the hand of government is very firmly on the tiller. The register of agreements indicates that a number of agreements benefiting from the Groceries PPEO were entered into on calls at which either the Prime Minister or Secretary of State participated. The line between government action and private action responding to clarion calls to act in the national interest is certainly blurred. To understand this, it is important to acknowledge just how central online grocery deliveries are to the 'stay at home' strategy. The UK government instruction is that the

63 Groceries PPEO, article 3(1)(b) and Explanatory Memorandum (fn 27), para 7.6. In Memorandum of understanding on the supply of oil fuels in an emergency (fn 12), para 69, measures were seen as compatible with s 9 of the 1998 Act in part because there was no agreement on price. In Coles Group Limited - Application for authorisation AA1000477 (fn 29), the ACCC considers a return to vigorous competition is likely owing to the temporary nature of the exclusion, the limited scope of the behaviour covered, oversight of the behaviour by a government department, the exclusion of price agreements, and the voluntary nature of the arrangements.

64 CMA approach to essential business cooperation (fn 12), para 2.4(a).

65 D. Bailey and L. John (eds), Bellamy \& Child European Union Law of Competition (8th edn), para 11.005.

66 G. Monti, 'Business Cooperation in Times of Emergency: The Role of Competition Law' in Competition Policy International (May 2020).

67 Supermarkets to join forces to feed the nation (fn 5). 
general population 'should not be going shopping except for essentials like food and medicine - and ... should do this as little as [they] can. And use food delivery services where [they] can' ${ }^{68}$ The government has additionally identified approximately 1.5 million people who should engage in social shielding as they are clinically extremely vulnerable. ${ }^{69}$ This group should not leave their home for 12 weeks, ask family, friends and neighbours for help obtaining food and medicines and should use online services.

Although we are supposed to stay at home and shop online, online groceries constituted just $6 \%$ of grocery sales prior to the COVID-19 pandemic. ${ }^{70}$ The service is also seen as particularly difficult to scale quickly, not least because of the need for delivery vehicles which can hold frozen, chilled and ambient goods. How will this scarce service be allocated during the COVID-19 pandemic? The market response would see the service allocated either to pre-existing, loyal customers or to those willing and able to pay the most. What has instead occurred is a departure from market norms to ensure that vulnerable groups are prioritized. There is certainly an expectation that grocery suppliers will cooperate to ensure such groups are served, as is clear not only from Article 3(2)(f) of the Groceries PPEO but also from the provision of a list of vulnerable consumers to be used for the purpose of prioritization, despite data privacy concerns. It is thus, with remarkable prescience, that the Financial Times opined that

Ministers should not suspend competition rules without quid pro quos. Price caps may be necessary for some staple products. And home deliveries may have to be reserved for the sick and elderly. ${ }^{71}$

This has effectively transpired, alongside special opening times for seniors and NHS workers. What we begin to see is not far short of a universal service obligation to serve the vulnerable and ensure everyone in a society has access to groceries. It is clear, however, that such a response is not required by law. ${ }^{72}$

EU law has always taken a strict approach, so that action must be required - rather than encouraged or approved of - before a defence of state compulsion to a competition law infringement arises. ${ }^{73} \mathrm{~A}$ change of approach may however be presaged in the Commission's Temporary Framework for assessing antitrust issues stemming from the COVID-19 outbreak, which notes that:

The fact that a cooperation is encouraged and/or coordinated by a public authority (or carried out within a framework set up by the latter) is also a relevant factor to be taken into account to conclude that such cooperation would not be problematic under EU competition law or would not be an enforcement priority for the Commission. ${ }^{74}$

As information on the relevant agreements is published, and the level of government involvement and oversight becomes apparent, it may well be that the Groceries PPEO is seen to resemble the action taken by the ACCC, which has granted an interim authorization for supermarkets to enter into discussions and agreements designed to ensure supply and ensure distribution, particularly of retail products in short supply, to elderly and disadvantaged members of the public and those who may be unwell as a result of COVID-19. ${ }^{75}$ Like the Groceries PPEO, both government officials, minsters, and even the competition authority itself are involved in the fora at which these otherwise infringing agreements would be made. ${ }^{76}$
68 Prime Minister address to the nation on coronavirus (fn 3 ) (emphasis added).

69 Public Health England, Guidance on shielding and protecting people who are clinically extremely vulnerable from COVID-19 (last updated 5 May 2020), available at: https://www.gov.uk/government/publications/guidance-onshielding-and-protecting-extremely-vulnerable-persons-from-covid-19/ guidance-on-shielding-and-protecting-extremely-vulnerable-persons-fromcovid-19.

70 See CMA, Anticipated merger between J Sainsbury PLC and Asda Group Ltd, Final Report (25 April 2019), para 4.49. The CMA's Final Report gives the following market share figures for online grocery delivery: Tesco (40-50\%), Asda (10-20\%), Sainsbury's (10-20\%) and Ocado (10-20\%). Para 4.27 , however, gives markets shares for the retail supply of groceries, and it will be instructive to learn to what extent agreements registered under the Groceries PPEO are skewed towards online providers: Tesco (27\%); Sainsbury (15\%); Asda (14\%), Morrisons (10\%), Aldi (7\%), the Co-op (6\%), Lidl and Waitrose (each 5\%), M\&S (4\%), Iceland (2\%) and Ocado (1\%).

71 'UK supermarkets: wartime rules may apply', Financial Times (18 March 2020).

72 Schedule 3(5) to the 1998 Act provides an exclusion when the action of the parties is required by law. Conduct under the Groceries PPEO falls short in this regard as it is clear that there is a permission to engage in such action rather than a legal duty to do.

73 EU law also excludes an undertaking from liability when behaviour is required by law: Joined Cases C-359/95 P and C-379/95 P Commission and French Republic v. Ladbroke Racing Ltd EU:C:1997:531 and Case C-280/08 P Deutsche Telekom AG v. European Commission EU: C:2010:603, para 80.

74 Temporary Framework for assessing antitrust issues related to business cooperation in response to situations of urgency stemming from the current COVID-19 outbreak (fn 32), para 15 (emphasis added).

75 Coles Group Limited - Application for authorisation AA1000477 (fn 29), para 11, noted by S. Gallash, Look who's talking: Australia's telcos, banks and supermarkets granted exemption to cartel laws (3 April 2020), available at: http://www.swinburne.edu.au/news/latest-news/2020/04/look-whostalking-australias-telcos-banks-and-supermarkets-granted-exemptionto-cartel-laws.php.

76 Coles Group Limited - Application for authorisation AA1000477 (fn 29), para 6. Consider also the South African government block exemption granted to collective action being supervised by the South African Department of Health, Expansion of the scope of COVID-19 Block Exemption for the Health Care Sector, 2020 (available at: https://www.gov.za/sites/default/ files/gcis_document/202004/43215rg11084gon456.pdf) and European Commission, Comfort letter: coordination in the pharmaceutical industry to increase production and to improve supply of urgently needed critical hospital medicines to treat COVID-19 patients (fn 32), which also involves approval of information exchanges 'requested' by the Commissioner for Health and Food Safety and the Commission's Directorate- General for Health and Food Safety (DG SANTE) and in which the Commission will have a steering role in facilitating the exchanges. The business review 


\section{Conclusion}

The COVID-19 response highlights what has always been known - an emergency does not override competition law obligations. ${ }^{77}$ At the same time, experience shows that a crisis requires 'common rules and a liberal use of common sense'. ${ }^{78}$ The response by competition authorities around the globe emphasizes that it is also possible for competition to be balanced against other concerns. ${ }^{79}$ The action taken by competition authorities is consistent with their legal powers. Save where expressly authorized, they have merely indicated the circumstances in which enforcement action will be a priority, rather than whether third parties may take action. ${ }^{80}$ Whether this provide sufficient clarity depends on the likelihood of third-party action. The longer the disruption to the economy, the greater the impact and the more likely third parties may claim that their chance of survival is adversely impacted by anti-competitive behaviour. Can parties to agreements that infringe competition law determine for themselves that wider concerns mean that the concerns of competition law should be set aside? The lesson we should take from the adoption of the Groceries PPEO is that, in the UK at least, confidence that the parties will not be punished for a good faith assessment with which others subsequently disagree is not high. If self-assessment breaks down at the time it is needed the most, who is best placed to provide the necessary degree of certainty ${ }^{81}$ It is inevitable that the determination will create both winners and losers, and that the winners will not be determined by market forces - but by the decision to permit or restrain behaviour. For COVID-19 in the UK it is acknowledged that there must be political accountability for the decision to set aside competition law, and the consequences that decision will have, both for competitors, others in the supply chain, and for different consumer groups. The decision therefore rests with the Secretary of State. letter issued by the US Department of Justice to McKesson Corporation, Owens \& Minor, Inc., Cardinal Health, Inc., Medline Industries, Inc., and Henry Schein, Inc., Business Review Request Pursuant to COVID-19 Expedited Procedure (4 April 2020) also emphasizes the role of government in the cooperation to which comfort is granted; the letter is available at: https://www.justice.gov/atr/page/file/1266511/download.

77 Sir J. Vickers (fn 7), p 10, reminds us that 'that competition policy, like a puppy, is not just for Christmas'.

78 N. Kroes (fn 6), 717.
79 J. Fingleton (fn 7), pp. 12-13; G. Monti, 'Escaping the clutches of EU competition law' (2017) 42(5) European Law Review, 635-56; and N. Dunne, 'Public Interest and EU Competition Law' (2020) The Antitrust Bulletin.

80 Brook (fn 17)

81 On the weakness in self-assessment the COVID-19 crisis has exposed, see F. Costa-Cabral, Future-Mapping the Three Dimensions of EU Competition Law: Modernisation Now and After COVID-19 (21 April 2020), TILEC Discussion Paper No DP 2020-011, available at: https://ssrn.com/ abstract $=3581535$. 